\title{
Breast cancer hypothesis: a single cause for the majority of cases
}

\author{
Richard A Wiseman
}

\begin{abstract}
Study objective-The main cause of breast cancer remains unknown. Numerous causal factors or predisposing conditions have been proposed, but account for only a small percentage of the total disease. The current search for multiple causes is unavailing. This report explores whether any single aetiological agent may be responsible for the majority of cases, and attempts to define its properties.

Methods-Examination of all relevant epidemiological and biological evidence.

Main results-Genetic inheritance is not the main cause of breast cancer because most cases are sporadic, there is a low prevalence of family history, and genetically similar women have differing rates after migration. Environmental exposure, such as pollution by industrialisation, is not a major cause, as deduced from a spectrum of epidemiological data. The possibility of infection as cause is not persuasive as there is no direct biological evidence and no epidemiological support. Oestrogen status is closely related to breast cancer risk, but there are numerous inconsistencies and paradoxes. It is suggested that oestrogens are not the proximate agent but are promoters acting in concert with the causal agent. Dietary factors, and especially fat, are associated with the aetiology of breast cancer as shown by intervention and ecological correlation studies, but the evidence from case-control and cohort studies is inconsistent and contradictory.

Conclusions-The hypothesis that best fits the epidemiological data is that dietary fat is not itself the causal agent, but produces depletion of an essential factor that is normally protective against the development of breast cancer. Many of the observed inconsistencies in the epidemiology are explainable if deficiency of this agent is permissive for breast cancer to develop. Some properties of the putative agent are outlined, and research investigations proposed.

(F Epidemiol Community Health 2000;54:851-858)
\end{abstract}

Population Health,

London School of

Hygiene and Tropical

Medicine, Keppel

Street, London

WC1E 7HT

Correspondence to:

Dr Wiseman

(richard.wiseman@1shtm.ac.uk)

Accepted for publication 18 May 2000

The main cause of breast cancer remains unexplained by the known epidemiology. ${ }^{1-3}$ Most women who develop breast cancer are ostensibly at low risk. Various factors or predisposing conditions have been identified-the American Public Health Association list obesity, age over 30 years at first child, nulliparity and radiation-but they account for only $26 \%$ of the incidence at most $^{4}$ and even these are characteristics of secondary risk factors merely associated with factors that determine risk. An alternative hypothesis to multifactorial aetiology is that a single main entity is responsible for the majority of cases (of similar pathology), as with many other cancers.

This report examines the epidemiological evidence and, where appropriate, relevant biological data relating to breast cancer including genetic, external environmental and internal environmental factors. The hypothesis that best fits the data is that there is a single causal agent for the majority of cases, and that it is a deficiency of this agent that is responsible. An attempt is made to deduce what such an aetiological agent may be, how it interacts with other factors, and to define its properties.

\section{Methods}

A systematic search was made through Medline and BIDS (Bath Information and Data Service) for all epidemiological studies related to breast cancer and causation, particularly to the incidence of breast cancer susceptibility genes, to familial history, to breast cancer and diet, to breast cancer and infection, to oestrogen status, and to mammary tumours in animals. National and International Cancer Registration Statistics were searched. Further data and relevant biological evidence were supplemented from textbooks, other searches and references in publications.

\section{Results}

GENETICS

Genetic inheritance is an infrequent but not the main cause of breast cancer. The consensus is that breast cancer susceptibility or cancer predisposition genes are associated with only $4 \%-8 \%$ of breast cancer cases. ${ }^{5-7}$ It is apparent therefore that $92 \%-96 \%$ of cases are sporadic.

The risk of developing disease for carriers of germline mutations has been estimated at 54\% by age 60 years $^{8}$ or $92 \%$ lifetime risk. ${ }^{9}$ Thus $46 \%$ of carriers do not develop the disease by 60 years and $8 \%$ never develop the disease. That leaves unanswered the question of what agent is responsible for progression from genetic predisposition to cancer state in women who develop the disease, and why other genetic predisposition cannot be the sole agent. Therefore even for carriers of strong cancer susceptibility genes an environmental trigger is necessary for the disease to become manifest.

Secondly, there is a low incidence of family history in breast cancer patients; typically, $11 \%$ of breast cancer patients have a first degree 
Table 1 Breast cancer rates for Chinese and fapanese women, per 100000 woman years age adjusted to world standard for 1978-1982 in different locations

\begin{tabular}{llllll}
\hline Chinese & Shanghai & Singapore & Hong Kong & Bay Area SF & Hawaii \\
& 19.1 & 27.1 & 28.7 & 43.7 & 57.5 \\
fapanese & Osaka & Migayi (rural) & Los Angeles & Bay Area SF & Hawaii \\
& 19.7 & 25.0 & 36.2 & 48.9 & 50.1 \\
\hline
\end{tabular}

Table 2 Age standardised breast cancer incidence rates in selected industrialised and non-industrialised locations

\begin{tabular}{|c|c|c|c|}
\hline Country/region & $\begin{array}{l}\text { Age } \\
\text { standardised } \\
\text { rate }\end{array}$ & Country/region & $\begin{array}{l}\text { Age } \\
\text { standardised } \\
\text { rate }\end{array}$ \\
\hline \multicolumn{2}{|c|}{ Agricultural/non-industrialised } & \multicolumn{2}{|l|}{ Heavily industrialised } \\
\hline Canada, Ontario & 64.7 & German Federal Republic, Saarland & 56.8 \\
\hline Scotland, N.E. & 59.6 & England, Birmingham & 55.0 \\
\hline Iceland & 60.1 & German Democratic Republic & 41.4 \\
\hline Ireland & 59.7 & Poland, Warsaw & 32.4 \\
\hline
\end{tabular}

relative, compared with $5 \%$ of controls; less than $1 \%$ of patients have both a mother and sister with the disease. ${ }^{910}$

Thirdly, ethnic groups who share the same close gene pool have dissimilar rates after migration to different locations. Breast cancer rates among the Chinese, $93 \%$ of whom are of the Han race, ${ }^{11}$ vary twofold and threefold on migration, as do those of the genetically close Japanese $^{12}$ (see table 1). Thus environmental conditions powerfully modify breast cancer rates.

ENVIRONMENTAL EXPOSURE

Environmental exposure, such as pollution by industrialisation, is not the main cause of breast cancer.

\section{Location and ethnicity}

Singapore is a city state in which a number of ethnic groups have resided for some generations; it is a small island without diverse environments. Relative risk (95\% CI) of breast cancer, age adjusted, by Singapore born ethnic group for 1968-82 was: Chinese 1.00 (reference group), Malays $0.78(0.66,0.93)$ Indians $1.26(0.93,1.70) .^{13}$

Such dissimilar rates between ethnic groups living under the same environmental conditions are unlikely to be attributable to the external environment. A more plausible explanation is that different ethnic groups on migrating overseas caried with them their cultural and dietary habits.

\section{Rural versus urban}

Cancer rates in England and Wales reveal rural areas with higher rates than metropolitan/ urban, and vice versa. ${ }^{14}$ For women under 45 years, the incidence rates were similar in metropolitan, urban and rural areas but for over 45 years there was "a slight gradient of higher risks in rural than urban and metropolitan areas".

It thus seems that breast cancer distribution in English or Welsh ${ }^{15}$ counties is not associated with industrialision but is simply random with respect to urbanisation.
Social class

(1) England and Wales

The OPCS reported ${ }^{16}$ breast cancer proportional registration ratios (PPRs) for 1984 in women for each social class: Class $\mathrm{I}=121$; Class II = 109; Class IIIN = 109; Class IIIM = 89; Class IV $=80$; Class V $=78$.

Industrialisation throughout Britain in this time period, or regional variations in industrialisation, could not account for these social class differences.

\section{(2) Japan}

Standard mortality ratios in Japan, from a prospective study involving 142857 women, were ${ }^{17}$ : high strata (professional, managers) 23.6; middle strata (clerks, sales, service, factory workers) 13.7; low strata (agriculture, fishery, miners) 8.9.

Such differences in SMRs are unlikely to be attributable to industrialisation - which, if responsible for differences in breast cancer risk, are more likely to affect workers in the specific manufacture or industry rather than professional classes and managers.

Thus the social class differences reported from Britain and Japan strongly suggest that industrialisation is unlikely to be responsible for breast cancer.

\section{Industrialisation in different countries}

There are (see table 2) higher rates in many agricultural/non-industrialised countries as compared with heavily industrialised areas, as well as vice versa. ${ }^{12}$ Conversely, in a study of 65 counties in China, ${ }^{18}$ all of which were rural and relatively homogeneous with respect to industrialisation, breast cancer mortality rates varied fivefold (from 6.6 to 34.7 per 100 000).

Therefore the level of general industrialisation in a country or area is unrelated to the incidence of breast cancer.

INFECTION AND BREAST CANCER

Indirect data concerning retroviruses

Antibodies to murine mammary tumour virus (MuMTV) - a retrovirus causally associated with the development of mammary tumors in mice $^{19}$ - and antigens immunologically related to it, and MuMTV-like particles, have been identifed in human breast cancer cells. ${ }^{19-24} \mathrm{~A}$ retrovirus-like agent has been detected in monocytes of breast cancer patients ${ }^{25}$ as have RNA and DNA sequences identical to MuMTV. ${ }^{26-28}$ However, against this, MuMTV antibodies were also found in healthy controls $^{20}{ }^{29}$ and MuMTV-like antigens detected in lactating women without breast cancer. ${ }^{30}$

The indirect evidence may be attributable to the presence of endogenous retroviral sequences identical to sequences in MuMTV ${ }^{28}{ }^{31-33}$ or other factors. ${ }^{28}{ }^{34}$

Other agents - such as cytomegalovirushave been proposed, with speculation that late exposure to a common virus increases risk, ${ }^{35}$ but there is no experimental evidence and an absence of epidemiological support.

\section{Absence of direct evidence}

There is no direct evidence-such as isolation of the retrovirus from cancerous tissue or ductal aspirates, or passage to breast cells. It is 
possible that the normal human breast contains retroviral sequences, identical to those in MuMTV, thus accounting for the presence of both antigens and antibodies.

Epidemiology of an infecting agent

The geographical and ethnic epidemiology is consistent with an infective theory. An infecting agent is likely to be transmitted by breast feeding, but (a) relative risk for mother-daughter incidence compared with controls in the large CASH Study was only 2.1 (95\% CI 1.7, 2.6) $)^{36}$; (b) breast fed infants as compared with bottle fed were shown to have a decreased risk in some studies, ${ }^{37}{ }^{38}$ while others showed no association ${ }^{39}$; and (c) no increased risk was found in daughters breast fed by mothers who later developed breast cancer. ${ }^{38}$ None of these findings are consistent with vertical transmission. There is no evidence either of horizontal transmission - that is, by direct person to person contact.

Thus the possibility of an infection being the causal agent of human breast cancer is not persuasive although an infective cause cannot be disregarded.

THE INTERNAL ENVIRONMENT

Oestrogens

Cumulative exposure to oestrogens is associated with most known risk factors, ${ }^{1}{ }^{40-42}$ but the theory that oestrogens are a necessary part of risk has numerous inconsistencies and paradoxes:

- pregnant women: there are no reliable statistical data regarding the incidence of breast cancer during pregnancy, but all reports indicate that it is either rare or no more frequent than in non-pregnant women ${ }^{43}$ despite the surge of oestrogens during pregnancy ${ }^{45} 46$

- postmenopausal women normally have oestradiol levels at approximately one third that of the lowest premenopausal level, ${ }^{41}$ yet the majority of breast cancers occur paradoxically in postmenopausal women;

- postmenopausal women taking HRT have raised oestrogen levels. Some studies reported raised breast cancer rates, ${ }^{5}{ }^{47-49}$ others observed no increase in risk,,$^{50-53}$ and one reported a decreased risk compared with controls. $^{54}$ A re-analysis in 1997 of the worldwide data, based on 51 studies and 53865 postmenopausal women, ${ }^{55}$ showed an increased risk comparable to delaying the menopause; the risk increased with increased duration of use. A comprehensive review noted that since 1941 there have been 71 epidemiological studies of the oestrogen-breast cancer link, of which 27 showed a slight increase in risk, 32 showed no difference, and 10 a slight decrease, and concluded that the excess risk is exceedingly small or non-existent. ${ }^{56}$

- long term administration of oestrogens to premenopausal women, as with oral contraceptives, has not caused a large increase in incidence - one early study found a trend to decreased risk, ${ }^{57}$ while most studies agree there is no excess risk ${ }^{58-61}$ or at most a small one in recently exposed women only ${ }^{61}$ or associated with long term use ${ }^{62}$ or in other subgroups related to age or timing of use..$^{63-66}$

- although higher serum concentrations of oestradiol - a meta-analysis calculated 15\% higher ${ }^{67}$ - have been reported in breast cancer cases as compared with controls, ${ }^{68}$ other studies found no differences. ${ }^{69} 70$

- men develop breast cancer-the majority are normal men, ${ }^{71}$ with normal high level of androgens, proven male fertility, ${ }^{73}$ and normal oestradiol levels. ${ }^{71}$

- breast cancer is rarely reported in men having oestrogen treatment for prostatic cancer. ${ }^{74} 75$

Accordingly, it seems that oestrogens are not the proximate cause of breast cancer, but are permissive, acting as promoters in concert with a causative agent.

DIET

Animal experiments

Animal experiments have repeatedly shown that mice or rats consuming a high fat diet have a higher mammary tumour incidence than those on a basic or restricted fat diet. ${ }^{76-80}$ The higher incidence is age dependent, the high fat diet causes a significant shortening of time to tumour appearance ${ }^{76}$ and the longer the duration the greater the development of mammary tumours. ${ }^{81}{ }^{82}$ Energy intake affects tumour incidence but is a separate and not a confounding factor. ${ }^{83-85}$

Ecological correlation studies

Many studies reported highly significant correlations between consumption of fats and mortality from breast cancer, ${ }^{86-88}$ including reports from the UK, ${ }^{89}{ }^{90}$ the USA,,${ }^{92}$ China, ${ }^{18}$ and Japan. ${ }^{17}$ The correlation is maximal for diet mortality intervals of 10 years $^{91}$ or 12 years. ${ }^{90}$ There were highly negative associations for cereal consumption. ${ }^{178990}$

Other national and cross national ecological correlation studies have confirmed the positive associations of breast cancer mortality and/or incidence with fat intake, and usually negative correlations with cereals and pulses. ${ }^{93-96} \mathrm{Re}-$ views of the data have come to the same conclusion. ${ }^{97-101}$

Ecological correlation studies in cancer have been justifiably criticised ${ }^{102}$ on various grounds, but for breast cancer they show strength, direction, consistency and predictability.

\section{Intervention studies}

(i) The Women's Health Trial in the USA

To investigate the effects of a low fat diet on breast cancer, women at increased risk were randomised into a dietary intervention group - a reduction of total daily fat intake by $60 \%$-or control. ${ }^{103}$ Results from the Seattle participants 3.5 years after randomisation showed a $15 \%$ reduction in breast cancer incidence.

\section{(ii) Fat and DNA damage}

Twenty one women with at least one first degree relative diagnosed with breast cancer were randomised to a non-intervention group who had their usual diets or to a group taking a low fat diet developed by the American Health 
Foundation. ${ }^{104}$ Decreased fat intake significantly decreased systematic oxidative stress as shown by DNA damage to leucocytes.

(iii) Wartime in Norway

Breast cancer incidence in Norwegian women who were pubescent or post-pubescent before, during or just after the second world war were compared ${ }^{105}$ and fitted to an age cohort model (fig 1). There was a definite break in cancer incidence during and after the war, being lower among women who experienced puberty during the war. The incidence rose again after the war.

(iv) Wartime in United Kingdom

Trend data showed that breast cancer mortality fell (by over 12\%) at the start of the second world war and stayed at the lower level until 1956. It was highly significantly and positively correlated with consumption of meat, fat and sugar, and highly negatively correlated with consumption of cereals. ${ }^{90}$

The conclusions from intervention studies are that diet plays an essential part in breast cancer incidence, and that changes in diet do not need decades for the effect to become manifest, but can act within a short time span.

Case-control and cohort studies

(i) Weight and obesity

For premenopausal women studies of risk and weight are inconsistent, while for postmenopausal women there is fairly consistent evidence of weight being associated with an increased risk of breast cancer, ${ }^{55}{ }^{106-109}$ particularly weight gain in adulthood ${ }^{106}$ and central obesity. ${ }^{70} 110-113$ There is a strong trend of increasing risk with increasing adiposity, recent adiposity influencing breast cancer risk more than early adiposity. ${ }^{114}$ This reinforces the point that changes in diet do not need decades for the effect on breast cancer incidence to become manifest.

(ii) Dietary fat

Reviews of case-control studies were varied, but concluded that they did not provide strong support for an association, ${ }^{101}$ that the published reports were inconsistent, ${ }^{115}$ and that, there was at most a weak and inconsistent association with breast cancer incidence.

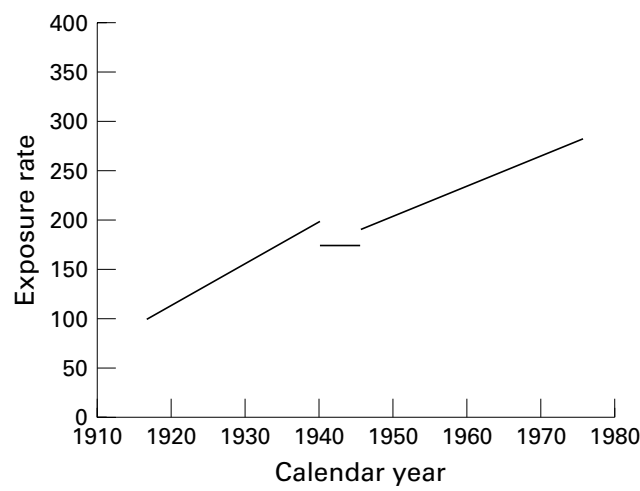

Figure 1 Wartime in Norway. Birth cohort-estimated exposure variable for breast cancer by calender year (year 1916 = 100). From: Tretli $S$ and Gaard H. Lifestyle changes during adolescence and risk of breast cancer: an ecologic study of the effect of World War II in Norway. Cancer Causes Control 1996;7:509 (fig 3). Reproduced by kind permission of Klewer Academic Publishers.
KEY POINTS

- The main cause of breast cancer remains unexplained by the known epidemiology. The search for multiple causes has been unsuccesful. This report explores whether a single causal agent may be responsible for the majority of cases.

- Published epidemiology indicates that genetic predisposition is not the main cause, nor are environmental exposures, nor infection; oestrogens are promoters but not the main agent.

- Dietary factors and especially fat consumption are associated with breast cancer. However, the hypothesis that best fits the data is that dietary fat is not itself the causal agent but instead causes depletion of an essential agent that is normally protective against breast cancer.

- Deficiency of this agent, by limited intake combined with the depletive effect of high fat diet interacting with age and oestrogen status, explains many of the inconsistencies in the epidemiology.

Prospective studies of fat intake, many of which were large with substantial statistical power to detect an effect if there was one, were reviewed comprehensively by the COMA Working Group ${ }^{106}$ and other reviewers, ${ }^{97} 102116117$ who concluded that the evidence was moderately consistent that no association exists between fat intake and breast cancer, but that, if an association does exist, the effect is likely to be small.

(iii) Meat consumption

The COMA review ${ }^{106}$ observed greater risks with higher meat intake in 17 of 20 casecontrol studies (despite possible recall bias ${ }^{118}$ ) and significantly higher risks (RRs $1.8-2.4$ ) in some prospective studies. ${ }^{119-123}$ but others found no association. ${ }^{124}{ }^{125}$ The consensus was that cohort studies are moderately consistent that meat consumption is associated with higher risk.

\section{Discussion}

REASONS FOR DISCREPANT RESULTS

Ecological correlation and intervention studies show a beneficial effect from reduction of total daily fat intake (as do animal experiments) whereas the case-control and cohort studies are inconsistent, although the larger prospective studies show little or no effect on risk of dietary fat but probably some increased risk associated with high meat consumption. There may be methodological reasons for these differences, for example, selection bias or recall bias in case-control studies, confounding in cohort and case-control studies-but such discrepancies could be more reliably explained if we posit the existence of an additional factor, a causal agent of breast cancer acting in conjunction with dietary fat, which has not as yet been taken into account. 
FATS AND OESTROGENS ARE NOT SUFFICIENT If fat-whether dietary fat, or obesity, or increased hip-waist ratio-is the sole dietary cause of breast cancer, it is difficult to explain the discrepancies between the ecological correlation plus intervention studies as contrasted with studies in individuals. Small increases in relative risk, even if statistically significant, could also not account for the large differences in breast cancer incidence in different locations or between different ethnic groups.

Thus the epidemiology indicates that fat is often associated with risk, but as it is neither necessary in all cases, nor sufficient on its own, it is probably a vehicle for another factor, which may or may not be present.

Oestrogens are also involved, but the numerous contradictions and paradoxes show that they are neither necessary (witness men with breast cancer) nor sufficient in themselves (for example, ethnic risk differences in women with normal levels) and thus are probably simply "permissive", acting, when present, as promoters.

The effect of fat and oestrogens in conjunction is the simplest and most parsimonious model for breast cancer causation, which model would be viable if fats contained a stimulating agent carcinogenic for breast tissue. However, fat and oestrogens together are not sufficient; if they were:

- no "thin" women with low dietary fat intake and normal oestrogen levels would develop breast cancer.

- a dose response relation should be presentincreasing dietary fat in women with normal oestrogen levels should be paralleled by an increasing incidence of breast cancer.

- similar levels of fat intake between populations would result in similar rates of breast cancer-but there is evidence directly contradicting this. ${ }^{18}$

- fat men with increased oestrogen or low androgen levels should develop breast cancer; but thin men with normal male hormonal balance would not.

Therefore some factor additonal to the fat/oestrogen interaction is involved in the initiation or promotion of breast cancer.

DEPLETION OF PROTECTIVE AGENT

The hypothesis that best fits the epidemiological data is that dietary fat is associated with breast cancer risk but is itself not the causal agent; instead high fat intake produces depletion of an essential factor, this factor or agent normally being protective against the development of breast cancer. Deficiency of this agent, perhaps after some latent interval, and probably with a threshold level, permits breast cancer to develop. Increased fat intake, as in a Western diet, causes systemic depletion or depletion in breast tissue of this factor. Increased intake of the agent, or foodstuffs containing it, prevent depletion.

This hypothesis explains a number of inconsistencies in the descriptive epidemiology, as follows:

\section{(i) Deficiency gradient}

Women with genetic predisposition need only minor degrees of the deficiency; women with sporadic cancer require a moderate deficiency; women with bilateral cancer will have severe deficiency; and men with breast cancer will have extreme depletion. Oestrogens are promoters making it easier for a carcinoma to develop, or to progress, but they are not necessary if the depletion is sufficiently severe.

\section{(ii) Age gradient}

An age related decrease of the protective agent would result in (a) the observed increased incidence of breast cancer with increasing age, and (b) the relation between weight and breast cancer incidence-the absence of excess risk in women under 50 years ${ }^{109}$ being attributable to high levels of the agent despite excess fat consumption, whereas natural decline after 50 years combined with depletion caused by high fat intake increases breast cancer incidence.

\section{(iii) Geographical variations}

High concentrations in the soil or plants, and consequently in the foodstuffs, in some countries accounts for areas where breast cancer incidence is traditionally low; conversely, low concentrations of the agent combined with a fatty diet accounts for traditionally high areas. High concentrations of this agent in Japanese foodstuffs, and low concentrations in Western foodstuffs, explain why overweight Japanese women have a lower incidence than Dutch women who are actually lighter. ${ }^{109}$

\section{(iv) Ethnic and social class variations}

The spread of a Western fatty diet has caused depletion of the agent in various populations, accounting for example for rate differences in Asians who migrated to the USA, and low rates in Chinese and Japanese (low fat diet, natural high levels of the agent in foodstuffs).

Previous social class differences in the United Kingdom occurred because foods that cause depletion (meat, milk) were consumed to a greater extent by the higher social groups. This dietary habit has now been reversed, explaining the change in observed incidence between the social classes.

\section{(v) Oestrogen interaction}

Oestrogens are tumour promoters, stimulating oestrogen dependent breast tissue when levels of the agent fall below a specific threshold. In areas or populations where tissue levels of the agent are low, hormonally mediated events that cause high oestrogen concentrations will be associated with increased risk, but where women are protected by high levels of the agent no excess risk will be found despite oestrogenic stimulation.

\section{PROPERTIES OF THE AGENT}

The agent is a micro-nutrient or trace element present in soils, found in varying amounts in different localities, taken up by plants, grains, fruits, to enter the food chain, present at high levels in, and readily available from, cereals and pulses, but present at only low levels in, or not available from, fat, red meat, or dairy products. 
FUTURE RESEARCH

If the hypothesis is correct, then animals given high doses of the agent will have lower rates of induced mammary tumours than control groups not given the agent, or groups with agent depletion; and in humans, concentrations of the agent will vary according to the genetic and gender deficiency gradient, age gradient, and geographical, ethnic and social class differences described above.

Research into the properties and concentrations of a spectrum of micro-nutrients, trace elements, antibodies to infective agents, and vitamins, should reveal if any fits the above criteria. If such an agent is detected, then intervention studies with supplementation should lead to a decline in the incidence of breast cancer.

The author is most grateful to Professor Klim McPherson, Cancer and Public Health Unit, London School of Hygiene and Tropical Medicine, for numerous suggestions and revisions, and to Professor Elizabeth Barrett-Connor, Chief Division of Epidemiology, University of California San Diego, for critical Epidemiology, University of California San
but helpful comments on the manuscript.

Funding: none.

Conflicts of interest: none.

1 Brinton LA, Devesa SS. Etiology and pathogenesis of breast cancer. In: Harris JR, Lippman ME, Morrow M, et al, eds.
Diseases of the breast. Philadelphia: Lippincott-Raven, Diseases of the

2 Lynch HT. Introduction to breast cancer genetics. In: Genetics and breast cancer. New York: Van Nostrand Reinhold Company, 1981:1-13.

3 Russo J, Russo IH. Toward a unified concept of mammary carcinogenesis. In: Aldaz CM, Gould MN, McLachlan J, et al, eds. Etiology of breast and gynecological cancers. New York: Wiley-Liss, 1997:1-16.

4 Brownson RC, Reif JS, Alavanja MCR, edt al. Cancer. In: Brownson RC, Remington PL, Davis JR, eds. Chroni disease epidemiology and control. American Public Health Association. Baltimore: Port City Press, 1993 151-52.

5 Colditz GA, Willett WC, Hunter DJ, et al. Family history, age and risk of breast cancer. $\mathcal{F} A M A$ 1993;274:338.

6 Weber BL, Garber JE. Familial breast cancer. In: Harris JR, Lippman ME, Morrow M, et al, eds. Diseases of the breast.

7 Lancaster JM, Wiseman RW. Recent advances in the molecular genetics of hereditary breast and ovarian cancer. In: Aldaz CM, Gould MN, McLachlan J, et al, eds. Etiology of breast and gynecological cancers. New York: Wiley-Liss, 1997:31-51.

8 Easton DF, Ford D, Bishop DT, and the Breast Cancer Linkage Consortium. Breast and ovarian cancer incidence in the BRCA1-mutation carriers. Am $f$ Hum Genet 1995;56:265-71.

9 Claus EB, Risch N, Thompson WD. Genetic analysis of breast cancer in the Cancer and Steroid Hormone Study. Am f Hum Genet 1991;48:232-42.

10 Sattin RW, Rubin GL, Webster LA, et al. Family history and the risk of breast cancer. $\mathcal{F} A M A$ 1985;253:1908-13.

11 New Encyclopaedia Brittanica 15th ed. China. Chicago: Encyclop Britt Inc, University of Chicago, 1988;3:229.

12 Muir C, Waterhouse J, Mack T, et al, eds. Cancer incidence in five continents, vol 5. IARC Scientific Publications no 88. five continents, vol 5 .

13 Lee HP, Day NE, Shanmugaratnam K. Trends in cancer incidence in Singapore 1968-1982. IARC Scientific Publications no 91. Lyon: IARC, 1988.

14 Swerdlow A, dos Santos Silva I. Atlas of cancer incidence in England and Wales 1968-85. Oxford: Oxford University Press, 1993.

15 Welsh Office. Cancer registration in Wales: 1974-1984. Pontypool: Mid Wales Litho, 1988.

16 Office of Population Censuses and Surveys. Cancer Statistics Registrations. Registrations of cancer diagnosed in 1984, England and Wales. Series MBI no. 16. London: The Stationery Office, 1988

17 Hirayama T. Epidemiology of breast cancer with special reference to the role of diet. Prev Med 1978;7:173-95.

18 Marshall JR, Yinsheng Q, Junshi C, et al. Additional ecological evidence: lipids and breast cancer mortality among women aged 55 and over in China. Eur $\mathcal{f}$ Cancer among women aged

19 Moore DH, Charney J, Kramarsky B, et al. Search for a human breast cancer virus. Nature 1971;229:611-15.
20 Day NK, Witkin SS, Sarkar NH, et al. Geographic and family studies of immunological responses to antigens of the murine mammary tumor virus in sera of patients with

1 Mesa-Tejada R, Keydar I, Ramanarayanan M, et al. Detection in human breast carcinomas of an antigen immunologically related to a group-specific antigen of mouse mammary tumor virus. Proc Natl Acad Sci USA 1978;75:152933.

22 Ohno T, Mesa-Tejada R, Keydar I, et al. Human breast carcinoma antigen is immunologically related to the polypeptide of the group-specific glycoprotein of mouse mammary tumor virus. Proc Natl Acad Sci USA 1979;76:2460-4.

23 Lloyd RV, Rosen PP, Sarkar NH, et al. Murine mammary tumor virus related antigen in human male mammary carcinoma. Cancer 1983;51:654-61.

24 Witkin SS, Sarkar NH, Kinne DW, et al. Antibodies Reactive with the mouse mammary tumor virus in sera of breast cancer patients. Int $\mathcal{F}$ Cancer 1980;25:721-5.

25 Al-Sumidaie AM, Leinster SJ, Hart CA, et al. Particles with properties of retroviruses in monocytes from patients with breast cancer. Lancet 1988;i:5-9.

26 Axel R, Schlom J, Spiegelman S. Presence in human breast cancer of RNA homologous to mouse mammary tumor virus RNA. Nature 1972;235:32-6.

27 Spiegleman S, Baxt W, Kufe D, et al. Sequences related to the RNA tumor viruses in the RNA and DNA of human leukemias and lymphomas. In: Ito Y, Dutcher RM, eds. Comparative leukemia research 1973. Tokyo: University of Tokyo Press, 1975:3-25.

28 May FEB, Westley BR. Characterisation of sequences related to the mouse mammary tumor virus that are specific to MCF-7 breast cancer cells. Cancer Res 1989;49: 3879-83.

29 Day NK, Witkin SS, Sarkar NH, et al. Antibodies reactive with murine mammary tumor virus in sera of patients with breast cancer: geographic and family studies. Proc Natl Acad Sci USA 1981;78:2483-7.

30 Zotter ST, Kemmer CHR, Lossnitzer A, et al. Mouse mammary tumour virus-related antigens in core-like density fractions from large samples of women's milk. Eur f Cancer 1980;16:455-67.

31 Ono M, Yasunaga T, Miyata $T$, et al. Nucleotide sequence of human endogenous retrovirus genome related to the mouse mammary tumor virus genome. $\mathcal{F}$ Virol 1986;60:589-98.

32 Faff $\mathrm{O}$, Murray AB, Schmidt J, et al. Retrovirus-like particles from the human T47D cell line are related to mouse mammary tumour virus and are of human endogenous origin. $\mathcal{F}$ Gen Virol 1992;73:1087-97.

33 Moyret C, Bernard D, Bignon YJ, et al. Presence of the mouse mammary tumour virus (MMTV) pol gene in breast cancer. Int f Oncol 1992;1:475-80.

34 Hareuven M, Lathe R. Breast cancer sequences identified by mouse mammary tumor virus (MMTV) antiserum are unrelated to MMTV. Int 7 Cancer 1990;46:1134-5.

35 Richardson $\mathrm{A}$. Is breast cancer caused by late exposure to a common virus? Med Hypotheses 1997;48:491-7.

36 Sattin RW, Rubin GL, Webster LA, et al. Family history and the risk of breast cancer. $\mathcal{F A M A} 1985 ; 253: 1908-13$.

37 Freudenheim JL, Marshall JR, Graham S, et al. Exposure to breastmilk in infancy and the risk of breast cancer. Epidemiology 1994;5:324-31.

38 Titus-Ernstoff L, Egan KM, Newcomb PA, et al. Exposure to breast milk in infancy and adult breast cancer risk. $\mathcal{F}$ Natl Cancer Inst 1998;90:921-4.

39 Ekbom A, Hsieh C-C, Trichopoulos D, et al. Breast-feeding and breast cancer in the offspring. Br f Cancer 1993;67: $842-5$.

40 Wynder EL, Bross IJ, Hirayama T. A study of the epidemiology of cancer of the breast. Cancer 1960;13:559-601.

41 Pike MC, Spicer DV, Dahmoush L, et al. Oestrogens, progestogens, normal cell proliferation, and breast cancer risk. Epidemiol Rev 1993;15:17-35.

42 Davis DL, Axelrod D, Osborne M, et al. Avoidable causes of breast cancer: the known, unkown, and the suspected. In: Bradlow HL, Fishman J, Osborne MP, eds. Cancer genetics and the environment. Ann NY Acad Sci 1997;833:112-28.

43 Petrek JA. Breast cancer and pregnancy. In: Harris JR, Lippman ME, Morrow M, et al, eds. Diseases of the breast. Philadelphia: Lippincott-Raven, 1996:883-92.

44 Hoover HC Jr. Breast cancer during pregnancy and lactation. Surg Clin North Am 1990;70:1151-63.

45 Shearman RP. Endocrine changes during pregnancy. In: Whitfield CR, ed. Dewhurst's textbook of obstetrics and gynae-cology for postgraduates. 4th ed. Oxford: Blackwell Scientific Publications, 1986:119-20.

46 Speroff L, Glass RH, Kase NG. The Endoctrinology of pregnancy. In: Speroff L, Glass RH, Kase NG, eds. Clinical gynecologic endo-crinology and infertility. 4th ed. Baltimore: Wilkins and Wilkins, 1989:317-50

7 Hunt K, Vessey M, McPherson K, et al. Long-term surveilance of mortality and cancer incidence in women receiving hormone replacement therapy. $\mathrm{Br} \mathcal{F}$ Obstet Gynaecol 1987;94:620-35.

48 Fraser GE, Shavlik D. Risk factors, lifetime risk, and age at onset of breast cancer. Ann Epidemiol 1997;7:375-82.

49 Ross RK, Paganini-Hill A, Wan PC, et al. Effect of hormone-replacement therapy on breast cancer risk: estrogen versus estrogen plus progestin. F Natl Cancer Inst. 2000; 92:328-32.

50 Wingo PA, Layde PM, Lee NC, et al. The risk of breast cancer in postmenopausal women who have used oestrogen replacement therapy. FAMA 1987;257:209-15. 
51 Armstrong BK. Oestrogen therapy after the menopauseboon or bane? Med F Aust 1988;148:213-14.

52 Stanford JL, Weiss NS, Voigt LF, et al. Combined oestrogen and progestin hormone replacement therapy in relation to risk of breast cancer in midlle-aged women. $f A M A$ 1995;274:137-42.

53 Soini I. Risk factors of breast cancer in Finland. Int $\mathcal{F}$ Epidemiol 1977;6:365-73

$54 \mathrm{Ng} \mathrm{E-H,} \mathrm{Gao} \mathrm{F,} \mathrm{Ji} \mathrm{C-Y,} \mathrm{et} \mathrm{al.} \mathrm{Risk} \mathrm{factors} \mathrm{for} \mathrm{breast}$ carcinoma in Singaproean Chinese women. The role of central obesity. Cancer 1997;80:725-31.

55 Collaborative Group on Hormonal Factors in Breast Cancer. Breast cancer and hormone replacement therapy: collaborative reanalysis of data from 51 epidemiological studies of 52705 women with breast cancer and 108411 women without breast cancer. Lancet 1997;350:1047-59.

56 Zumoff B. Does postmenopausal oestrogen administration increase the risk of breast cancer? Contributions of animal, biochemical, and clinical investigative studies to a resolution of the controversy. Proc Soc Exp Biol Med 1998;217: tion of

57 Vessey MP, Doll R, Sutton PM. Investigation of the possible relationship between oral contraceptives and benign and malignant breast disease. Cancer 1971;28:1395-9.

58 Hankinson SE, Colditz GA, Manson JE, et al. A prospective study of oral contraceptive use and risk of breast cancer (Nurses' Health Study). Cancer Causes Control 1997;8:6572 .

59 Newcomb PA, Longnecker MP, Storer BE, et al. Recent oral contraceptive use and risk of breast cancer. Cancer Causes Control 1996;7:525-32.

60 Stavraky K, Emmons S. Breast cancer in premenopausal and postmenopausal women. I Nat Cancer Inst 1974;53: 647-54.

61 Beral V, Hermon C, Kay C, et al. Mortality associated with oral contraceptive use: 25 year follow up of cohort of 46000 women from Royal College of General Practitioners' oral contraception study. BMF 1999;318:96-100.

62 Meirik O, Lund E, Adami H-O, et al. Oral contraceptive use in relation to breast cancer. Lancet 1986;ii:650-3.

63 McPherson K, Vessey MP, Neil A, et al. Early oral contraceptive use and breast cancer: results of another case-control study. Br f Cancer 1987;56:653-60.

64 Pike MC, Henderson BE, Casagrande JT, et al. Oral contraceptive use and early abortion as risk factors for breast cancer in young women. Br f Cancer 1981;43:72-6.

65 Rookus MA, van Leeuwen FE. Oral contraceptives and risk of breast cancer in women aged 20-54 years. Lancet 1994 344:844-51.

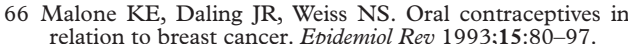

67 Thomas HV, Reeves GK, Key JA. Endogenous oestrogen and postmenopausal breast cancer: a quantitative review. and postmenopausal breast cancer:
Cancer Causes Control 1997;8:922-8.

68 Hankinson SE, Willett WC, Manson JE, et al. Plasma sex steroid hormone levels and risk of breast cancer in postmenopausal women. I Natl Cancer Inst 1998;90 $1292-9$.

69 Garland CF, Friedlander NJ, Barrett-Connor E, et al. Sex hormones and postmenopausal breast cancer: a prospective 1220-30.

70 Bruning PF, Bonfrer JMG, Hart AAM, et al. Body measurements, estrogen availability and the risk of human breast cancer: a case-control study. Int 7 Cancer 1992;51:14-19.

71 Casagrande JT, Hanisch R, Pike MC, et al. A case-control study of male breast cancer. Cancer Res 1988;48:1326-30.

72 Thomas DB, Jimenez LM, McTiernan A, et al. Breast cancer in men: risk factors with hormonal implications. Am $\mathcal{f}$

73 Mabuchi K, Bross DS, Kessler II. Risk factors for male breast cancer. $\mathcal{F}$ Natl Cancer Inst 1985;74:371-5.

74 McClure JA, Higgins CC. Bilateral carcinoma of the male breast after oestrogen therapy. $\mathcal{F} A M A$ 1951;146:7-9.

75 Schlappack OK, Braun O, Maier U. Report of two cases of male breast cancer after prolonged oestrogen treatment for prostatic carcinoma. Cancer Detec Prev 1986;9:319-22.

76 Tannenbaum A. The genesis and growth of tumours III Effects of a high-fat diet. Cancer Res 1942;2:468-75.

77 Benson J, Lev M, Grand CG. Enhancement of mammary fibroadenomas in the female rat by a high fat diet. Cancer Res 1956;16:135-7.

78 Davis RK, Setevenson GT, Busch KA. Tumor incidence in normal Sprague-Dawley female rats. Cancer Res 1956;16: normal

79 Carroll KK, Khor HT. Effects of level and type of dietary fat on incidence of mammary tumors induced in female Sprague-Dawley rats by 7, 12-dimethylbenz $(\alpha)$ anthracene. Lipids 1971;6:415-20.

80 Welsch CW. Relationship between dietary fat and experimental tumorigenesis: a review and critique. Cancer $R e$ 1992;52:2040-8s.

81 Aylsworth CF, Jone C, Trosko JE, et al. Promotion of 7,12dimethylbenz[a] anthracene-induced mammary tumorigenesis by high dietary fat in the rat: possible role of intercellular communication. 7 Natl Cancer Inst 1984;72;63745.

82 Dao TL, Chan P-C. Effect of duration of high fat intake on enhancement of mammary carcinogenesis in rats. $\mathcal{F}$ Nat Cancer Inst 1983;71:201-5.

83 Kritchevsky D, Weber MM, Klurfeld DM. Dietary fat versus caloric content in initiation and promotion of 7,12 dimethylbenz[a] anthracene-induced mammary tumorigenesis fat in the rat. Cancer Res 1984;44:3174-7.
84 Welsch CW, House JL, Herr BL, et al. Enhancement of mammary carcinogenesis by high levels of dietary fat: a phenomenon dependent on ad libitum feeding. $\mathcal{F}$ Natl Cancer Inst 1990;82:1615-20.

85 Freedman LS, Clifford C, Messina M. Analysis of dietary fat, calories, body weight, and the development of mammary tumors in rats and mice: a review. Cancer Res 1990;50:5710-19.

86 Lea AJ. Dietary factors associated with death-rates from certain neoplasms in man. Lancet 1966;ii:332-3.

87 Carroll KK, Gammal EB, Plunkett ER. Dietary fat and mammary cancer. Can Med Assoc f 1968;98:590-4.

88 Hems G. Epidemiological characteristics of breast cancer in middle and late age. Br f Cancer 1970;24:226-34.

89 Armstrong B, Doll R. Environmental factors and cancer incidence and mortality in different countries with special reference to dietary practices. Int $\mathcal{F}$ Cancer 1975;15: 617-31

90 Ingram DM. Trends in diet and breast cancer mortality in England and Wales 1928-1977. Nutr Cancer 1981;3:7580.

91 Enig MG, Munn RJ, Keeney M. Dietary fat and cancer trtends-a critique. Federation Proc 1978;37:2215-20.

92 Gaskill SP, McGuire WL, Osborne CK, et al. Breast cancer mortality and diet in the United States. Cancer Res 1979;39:3628-37.

93 Kato I, Tominaga S, Kuroishi T. Relationship between Westernization of dietary habits and mortality from breast and ovarian cancers in Japan. Fpn f Cancer Res 1987;78: 349-57.

94 Schatzkin A, Piantadosi S, Miccozzi M, et al. Alcohol consumption and breast cancer: a cross-national correlation study. Int $\mathcal{F}$ Epidemiol 1989;18;28-31.

95 Taioli E, Nicolosi A, Wynder EL. Dietary habits and breast cancer: a comparative study of United States and Italian data. Nutr Cancer 1991;16:259-65.

96 McMichael AJ, Giles GG. Cancer in migrants to Australia: extending the descriptive epidemiological data. Cancer Res 1988;48:751-6.

97 Goodwin PJ, Boyd NF. Critical appraisal of the evidence that dietary fat is related to breast cancer risk in humans. $\mathcal{F}$ that dietary fat is related to breast

98 correa p. Epidemiological correlations between diet and cancer frequency. Cancer Res 1981;41:3685-90

99 Hankin JH. Role of nutrition in women's health: diet and breast cancer. F Am Diet Assoc 1993;93:994-9.

100 Schatzkin A, Greenwald P, Byatt DP, et al. The dietary fatbreast cancer hypothesis is alive. $\mathcal{F} A M A$ 1989;261:3284-7.

101 RohanTE, Bain CJ. Diet in the aetiology of breast cancer. Epidemiol Rev 1987;9:120-45.

102 Hunter DJ, Willett WC. Aetiology and pathogenesis of breast cancer: dietary factors. In: Harris JR, Lippman ME, et al, eds. Diseases of the breast. Philadelphia: LippincottRaven, 1996:201-12.

103 Gorbach SL, Morrill-LaBrode A, Woods MN, et al. Changes in food patterns during a low-fat dietary intervention in women. $f$ Am Diet Assoc 1990;90:802-9.

104 Djuric Z, Martino S, Heilbrun LK, et al. Dietary modulation of oxidative DNA damage. In: Jacobs MM, ed. Diet and cancer: marker, prevention, and treatment. New York: Plenum Press, 1994:71-83.

105 Tretli S, Gaard M. Lifestyle changes during adolescence and risk of breast cancer: an ecologic study of the effect of world war II in Norway. Cancer Causes Control 1996;7:50712.

106 Committee on Medical Aspects of Food and Nutrition Policy (COMA): Report of the Working Group on Diet and Cancer. Nutritional aspects of the development of cancer. London: The Stationery Office, 1998.

107 Kuller LH. Dietary fat and chronic diseases: epidemiologic overview. F Am Diet Assoc 1997; 97 (suppl):S9-15.

08 Greenwald P, Sherwood K, McDonald SS. Fat, caloric intake, and obesity: lifestyle risk factors for breast cancer. $\mathcal{F}$ Am Diet Assoc 1997;97 (suppl):S24-30.

109 Waard de F, Cornelis JP, Aoki K, et al. Breast cancer incidence according to weight and height in two cities of the Netherlands and in Aichi prefecture, Japan. Cancer 1977;40:1269-75.

110 Schapira DV, Kumar NB, Lyman GH, et al. Abdominal obesity and breast cancer risk. Ann Intern Med 1990;112: $182-6$.

111 Ballard-Barbash R, Schatzkin A, Carter C, et al. Body fat distribution and breast cancer in the Framingham study. $\mathcal{F}$ Natl Cancer Inst 1990;82:286-90

112 Sellers TA, Kushi LH, Potter JD, et al. Effect of family history, body-fat distribution, and reproductive factors on the risk of postmenopausal breast cancer. N Engl F Med 1992; 326:1323-9.

113 Schapira DV, Clark RA, Wolff PA, et al. Visceral obesity and breast cancer risk. Cancer 1994;74:632-9.

114 Ziegler RG, Hoover RN, Nomura AMY, et al. Relative weight, weight change, height and breast cancer risk in Asian-American women. $\mathcal{F}$ Natl Cancer Inst 1996;88:65060.

115 Goodwin PJ, Boyd NF. Critical appraisal of the evidence that dietary fat is related to breast cancer risk in humans. $\mathcal{F}$ Natl Cancer Inst 1987;79:473-85.

116 Boyd NF, Martin LJ, Noffel M, et al. A meta-analysis of studies of dietary fat and breast cancer risk. Br $\mathcal{F}$ Cancer 1993;68:627-36.

117 Hunter DJ, Spiegelman D, Adami HO, et al. Cohort studies of fat intake and the risk of breast cancer - a pooled analysis. N Engl f Med 1996;334:356-61. 
118 Giovannucci E, Stampfer MJ, Colditz GA, et al. A comparison of prospective and retrospective assessment of diet in the tudy of breast and retrospective assessment of diet in

119 Toniolo P, Riboli E, Shore RE, Pasternack BS. Consumption of meat, animal products, protein, and risk of breast cancer: A prospective cohort study in New York. Epidemiology 1994;5:391-7.

120 Vatten LJ, Kvinnsland S. Body height and risk of breast cancer. A prospective study of 23,831 Norwegian women Br f Cancer 1990;61:881-5.

121 Knekt P, Steineck G, Jarvinen R, et al. Intake of fried meat and risk of cancer: a follow up study in Finland. Int 7 Cancer 1994;59:756-60.
122 Hirayama T. Lifestyle and mortality: a large-scale census-based cohort study in fapan. Basel: Karger, 1990.

123 Gaard H, Tretli S, Loken EB. Dietary fat and the risk of breast cancer. A prospective study of 25,892 Norwegian women. Int F Cancer 1995;63:13-17.

124 Willett WC, Hunter DJ, Stampfer MJ, et al. Dietary fat and fibre in relation to risk of breast cancer. An eight year follow up. F Am Med Assoc 1992;268:2037-44.

125 Phillips RL, Snowdon DA. Association of meat and coffee use with cancers of the large bowel, breast, and prostate among Seventh-Day Adventists: preliminary results. Cancer Res 1983;43 (suppl):2403-8s. 